\title{
PENGARUH RASIO PROFITABILITAS TERHADAP PERTUMBUHAN LABA DENGAN RASIO KINERJA OPERASI DAN RASIO PASAR SEBAGAI MODERATING VARIABEL PADA PERUSAHAAN MANUFAKTUR SEKTOR INDUSTRI DASAR DAN KIMIA TAHUN 2016-2018
}

\author{
Fajar Sari Septiyani ${ }^{1}$ \\ ${ }^{1}$ Fakultas Ekonomi Universitas Krisnadwipayana \\ Jalan Unkris Jatiwaringin Jakarta Timur \\ e-mail: fajarsari1609@gmail.com \\ Mishelei Loen ${ }^{2}$ \\ ${ }^{2}$ Fakultas Ekonomi Universitas Krisnadwipayana \\ Jalan Unkris Jatiwaringin Jakarta Timur \\ e-mail: mishelei.loen@gmail.com
}

\begin{abstract}
This research was conducted at Industrial and Chemical Sector Manufacturing Companies listed on the Indonesia Stock Exchange Period 2016-2018. The purpose of this study is to determine the Profitability Ratio to profit growth with the ratio of operating performance and market ratio as a moderating variable. The collection technique in this study the type of data used is secondary data while the method of analysis uses quantitative analysis. From the results of the research that has been done, it is obtained that the Profitability Ratio shows that there is a positive and significant effect on Profit Growth. The Operating Performance Ratio which moderates the Profitability Ratio to Profit Growth shows there is a negative and significant effect on Profit Growth. While the Market Ratio which moderates the Profitability Ratio to Profit Growth shows there is a negative and not significant effect on Profit Growth.
\end{abstract}

Keywords: Profitability Ratio, Operating Performance Ratio, Market Ratio and Profit Growth

\section{PENDAHULUAN}

Menurut FASB Statement of Financial Accounting Concepts No. 1 Par 4, tujuan utama dalam berdirinya suatu perusahaan adalah laba pada perusahaan tersebut, selain dalam berdirinya suatu perusahaan juga merupakan komponen utama dalam laporan keuangan dan laba pada suatu perusahaan di setiap periode diharapkan yang akan mengalami peningkatan dari periode sebelumnya, sehingga dalam hal ini dibutuhkan estimasi laba untuk pencapaian perusahaan untuk periode selanjutnya yang menjadi landasan informasi dari perkembangan perusahaan. Dalam kondisi perusahaan seperti ini berhasil atau tidaknya suatu perusahaan pada umumnya ditandai dengan kemampuan manajemen dalam melihat kemungkinan dan kesempatan di masa yang akan datang, baik jangka panjang maupun jangka pendek mengenai pertumbuhan labanya. Menurut Gunawan dan Wahyuni (2013), cara perhitungan pertumbuhan laba adalah dengan cara mengurangkan laba periode sekarang dengan laba periode sebelumnya kemudian dibagi dengan laba pada periode sebelumnya. Menurut Hendriksen dan Michael (2000), Statement of Financial Accounting Concepts No 1 menyatakan bahwa sasaran utama pelaporan keuangan 


\section{DOI: http://dx.doi.org/10.35137/jabk.v7i1.381}

adalah informasi tentang prestasi perusahaan yang disajikan melalui pengukuran laba dan komponennya.

Menurut Porter (1980), perusahaan yang bertumbuh adalah perusahaan yang memiliki pertumbuhan margin, maupun laba dan penjualan yang tinggi. Pertumbuhan laba yang tinggi dalam suatu perusahaan dapat mencerminkan kinerja perusahaan yang baik. Menurut Copeland dan Weston (1982), salah satu ukuran kinerja perusahaan adalah analisis rasio pertumbuhan. Kemampuan perusahaan untuk mempertahankan posisi ekonomisnya dalam pertumbuhan perekonomian diukur oleh rasio pertumbuhan. Pertumbuhan laba merupakan selisih laba bersih tahun tertentu dengan laba bersih tahun sebelumnya dibagi dengan laba bersih tahun sebelumnya, Hery (2017 : 3). Besarnya perusahaan, umur perusahaan, tingkat leverage, tingkat penjualan dan perubahan laba yang tinggi mengindikasikan laba yang diperoleh perusahaan tinggi, sehingga tingkat pembagian dividen perusahaan tinggi pula merupakan bagian dari faktor yang mempengaruhi pertumbuhan laba.

Penurunan laba yang dialami suatu perusahaan merupakan hambatan bagi kinerja operasional perusahaan hal ini disebabkan karena setiap perusahaan mengharapkan kenaikan laba dalam setiap periodenya. Oleh karena itu, diperlukan analisis laporan keuangan untuk menganalisis, mengestimasi laba dan mengambil keputusan atas pertumbuhan laba yang akan dicapai untuk periode waktu mendatang. Dalam mengukur kekuatan atau kelemahan yang dihadapi perusahaan di bidang keuangan yang pada dasarnya tidak hanya berguna bagi kepentingan intern perusahaan, melainkan juga bagi pihak ekstern digunakan alat analisis rasio keuangan. Rasio keuangan yang dipakai dalam penelitian ini adalah rasio profitabilitas, rasio kinerja operasi dan rasio pasar.

Kemampuan perusahaan dalam menghasilkan laba digambarkan dalam rasio profitabilitas. Menurut Hery (2017), rasio profitabilitas dapat dibedakan menjadi dua jenis, yaitu rasio tingkat pengembalian atas investasi dan rasio kinerja operasi. Rasio dalam penelitian ini berfokus pada Return On Aset (ROA). Apabila rasio tersebut mengalami peningkatan, maka profitabilitas perusahaan berarti membaik. Rasio ini dapat dijadikan acuan dalam perencanaan laba perusahaan pada tahun berikutnya.

Rasio yang digunakan untuk mengevaluasi marjin laba dari aktivitas operasi atau penjualan dinamakan rasio kinerja operasi. Rasio ini terdiri atas Marjin Laba Kotor (Gross Profit Margin), Marjin Laba Operasional (Operating Profit Margin) dan Marjin Laba Bersih (Net Profit Margin Kasmir. (2016)). Rasio dalam penelitian ini berfokus pada Net Profit Margin (NPM), yaitu rasio yang digunakan untuk mengukur sebarapa besarnya persentase laba bersih atas penjualan bersih. Apabila NPM meningkat maka profitabilitas perusahaan berarti membaik. Selain itu, rasio ini dapat dijadikan acuan untuk perencanaan laba perusahaan tahun berikutnya.

Rasio Pasar (Market Ratio) merupakan rasio yang digunakan dalam mengukur nilai saham. Rasio Pasar antara lain Earning Per Share (EPS) dan Price Book Value (PBV). Menurut Ang (1997), Earning Per Share (EPS) merupakan perbandingan antara laba bersih setelah pajak pada satu tahun buku dengan jumlah saham yang diterbitkan. Investor atau calon investor merupakan sudut pandang dalam rasio pasar, meskipun pihak manajemen juga berkepentingan 
ISSN : 2406-7415

e-ISSN : 2655-9919

JURNAL AKUNTANSI DAN BISNIS KRISNADWIPAYANA

Vol. 7 No. 1 (Januari - April) 2020

DOI: $\underline{\text { http://dx.doi.org/10.35137/jabk.v7i1.381 }}$

terhadap rasio-rasio ini. Salah satu rasio pasar yang digunakan dalam penelitian ini adalah EPS yang membandingkan antara harga pasar per lembar saham biasa yang beredar dengan laba per lembar saham.

Penulis juga melatar belakangi penelitian ini oleh perbedaan hasil penelitian atau research gap dari beberapa peneliti terdahulu menurut penelitian Meilyanti (2017), Febrianty dan Divianto (2017), Munte dan Sitanggang (2017), Afifah (2016), Andriani (2015) serta Oktatinus dan Adel (2018) menjelaskan bahwa secara simultan terdapat pengaruh signifikan antara rasio profitabilitas, rasio kinerja pasar terhadap pertumbuhan laba. Sedangkan Isnaniah (2016) menjelaskan bahwa rasio profitabilitas dan rasio kinerja operasi tidak berpengaruh negatif dan signifikan terhadap pertumbuhan laba dalam penelitian yang berjudul Pengaruh Rasio Keuangan terhadap Pertumbuhan Laba pada Perusahaan Manufaktur Sektor Industri Konsumsi yang terdaftar di Bursa Efek Indonesia (Studi kasus pada perusahaan Kalbe Farma Tbk periode 2007-2014). Penelitian ini dilakukan untuk menguji kembali hubungan rasio-rasio keuangan dengan pertumbuhan laba. Adanya ketidakkonsistenan hasil dari penelitian-penelitian sebelumnya menyebabkan isu ini menarik untuk diteliti kembali. Berdasarkan uraian tersebut di atas maka yang menjadi permasalahan dalam penelitian ini adalah sebagai berikut:

1. Apakah rasio profitabilitas berpengaruh terhadap pertumbuhan laba perusahaan manufaktur sektor industri dasar dan kimia yang terdaftar di BEI Periode Tahun 2016-2018?

2. Apakah rasio kinerja operasi memoderasi pengaruh rasio profitabilitas terhadap pertumbuhan laba perusahaan manufaktur sektor industri dasar dan kimia yang terdaftar di BEI Periode Tahun 2016-2018?

3. Apakah rasio kinerja pasar memoderasi pengaruh rasio profitabilitas terhadap pertumbuhan laba perusahaan manufaktur sektor industri dasar dan kimia yang terdaftar di BEI Periode Tahun 2016-2018?

\section{LANDASAN TEORI}

\section{Laporan Keuangan}

Menurut Hery (2017 : 3) laporan keuangan adalah hasil proses akuntansi yang dapat digunakan sebagai alat untuk mengkomunikasikan data keuangan atau aktivitas perusahaan kepada pihak-pihak yang berkepentingan. Dengan kata lain, laporan keuangan ini berfungsi sebagai alat informasi yang menghubungkan perusahaan dengan pihak-pihak yang berkepentingan, yang menunjukan kondisi kesehatan keuangan perusahaan dan kinerja perusahaan merupakan definisi laporan keuangan.

Wijaya (2017 : 13) menyatakan bahwa Bahasa bisnis merupakan Laporan Keuangan karena didalam laporan keuangan itu membuat informasi mengenai kondisi keuangan perusahaan kepada pihak penggunanya.

\section{Pertumbuhan Laba}

Menurut Harahap (2015 : 125), penguranggan laba periode sekarang dengan laba periode sebelumyan kemudian dibagi dengan laba periode sebelumnya merupakan perhitungan pertumbuhan laba. 


\section{DOI: $\underline{\text { http://dx.doi.org/10.35137/jabk.v7i1.381 }}$}

Pertumbuhan laba dapat diformulasikan sebagai berikut:

Pertumbuhan Laba $=$

$\underline{\text { (Laba Operasional t)-(Laba Operasional } t-1)}$ (Laba Operasional $t-1$ )

Pertumbuhan laba dipengaruhi oleh perubahan komponen-komponen dalam laporan keuangan. Perubahan komponen laporan keuangan disebabkan oleh misalnya perubahan penjualan, perubahan harga pokok penjualan, perubahan beban operasi, perubahan beban bunga, perubahan pajak penghasilan, adanya perubahan pada pospos luar biasa dan lain-lain

\section{Rasio Profitabilitas}

Rasio Profitabilitas adalah rasio yang menggambarkan suatu perusahaan dengan memberikan kemampuan dalam menghasilkan laba dengan kemampuan dan sumber yang dimiliki Kasmir. (2016). Menurut Ang (1997), rasio profitabilitas terdiri dari tujuh rasio dan dari ke tujuh rasio profitabilitas tersebut penelitian ini menggunakan salah satu yaitu rasio yang berkaitan dengan efisiensi perusahaan dalam menghasilkan laba, adalah Return On Assets (ROA). Rumus Return On Assets (ROA) adalah:

Return on Assets $(R O A)=\frac{\text { Net Income }}{\text { Total Asset }}$

\section{Rasio Kinerja Operasi}

Rasio kinerja operasi adalah rasio yang digunakan untuk mengevaluasi marjin laba dari aktivitas operasi perusahaan atau penjualan. Rasio ini terdiri atas Marjin Laba Kotor (Gross Profit Margin), Marjin Laba Operasional (Operating Profit Margin) dan Marjin Laba Bersih (Net Profit Margin Kasmir. (2016)). Penelitian ini menggunakan rasio Rasio Net Profit Margin
(NPM). Menurut Darsono dan Ashari (2005), Net Profit Margin (NPM) disebut juga dengan rasio pendapatan terhadap penjualan yaitu laba bersih dibagi penjualan bersih. Rasio ini menggambarkan sebagian besar laba bersih yang diperoleh perusahaan pada setiap penjualan yang dilakukan. Semakin besar nilai dari NPM, maka kinerja perusahaan akan semakin produktif, sehingga akan meningkatkan kepercayaan investor dalam hal menanamkan modalnya pada perusahaan tersebut. Dalam rasio ini menunjukkan sebesar apa persentase laba bersih yang diperoleh dari setiap penjualan. Semakin besar rasio ini, maka dianggap semakin baik kemampuan perusahaan dalam hal mendapatkan laba yang tinggi.

Net Profit Margin (NPM)

$=\frac{\text { Earning After Tax (EAT) }}{\text { Sales }}$

\section{Rasio Pasar}

Rasio pasar (market ratio) atau rasio saham adalah rasio yang digunakan untuk mengukur nilai saham. Rasio pasar antara lain Earning Per Share (EPS) dan Price Book Value (PBV). Penelitian ini menggunakan Earning Per Share (EPS) Kasmir. (2016). Menurut Ang (1997), perbandingan antara laba bersih setelah pajak pada satu tahun buku dengan jumlah saham yang diterbitkan merupakan nilai Earning Per Share (EPS). Earning Per Share (EPS) secara matematis dirumuskan sebagai berikut :

$$
\begin{aligned}
& \text { Earning Per Share (EPS) } \\
& \qquad=\frac{\text { Nett Income }}{\text { Jumlah Saham }}
\end{aligned}
$$

\section{Kerangka Konseptual}




\section{DOI: http://dx.doi.org/10.35137/jabk.v7i1.381}

Berdasarkan penelitian-penelitian terdahulu, maka peneliti menggambarkan kedalam kerangka penelitian berikut ini:

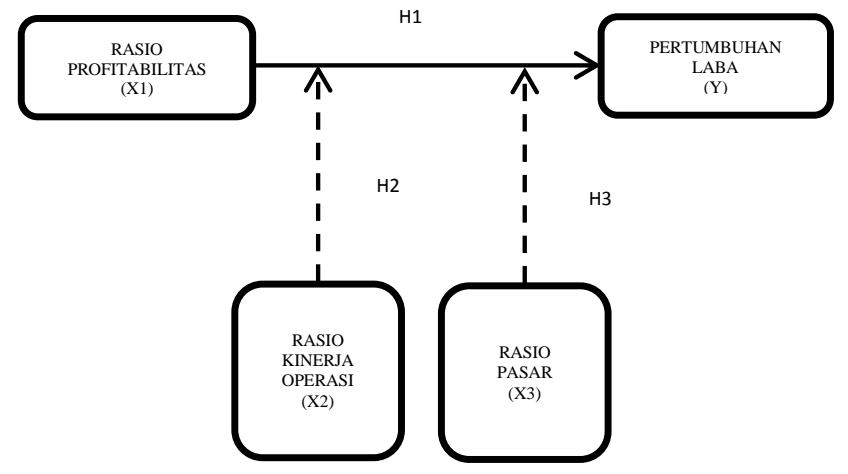

Gambar 1. Kerangka Penelitian

\section{Pengembangan Hipotesis}

Variabel - variabel fundamental dibawah ini merupakan faktor-faktor yang mempengaruhi pertumbuhan laba yang berdasarkan penelitian terdahulu dan memiliki hubungan terhadap pertumbuhan laba. Variabel-variabel fundamental tersebut adalah sebagai berikut : Rasio Profitabilitas, Rasio Kinerja Operasi dan Rasio Pasar.

\section{Rasio Proftabilitas Terhadap Pertumbuhan Laba}

Suatu laporan keuangan dibuat secara berkala baik bulanan, kuarter, semesteran atau tahunan oleh suatu perusahaan dalam hal melaporkan kinerja keuangannya. Laporan keuangan yang dibuat umumnya adalah laporan laba rugi, neraca, arus kas, perubahan modal dan catatan atas laporan keuangan. Profitabilitas berdasarkan asset diperoleh melalui perbandingan antara laba bersih setelah pajak yang diperoleh dari laporan laba rugi dengan total aset yang dimiliki selama periode tertentu tercermin pada neraca. Semakin tinggi profitabilitas maka semakin baik kinerja keuangan suatu perusahaan. Tingginya nilai profitabilitas dalam suatu perusahaan mencerminkan laba suatu perusahaan.

Penelitian tentang pengaruh profitabilitas dengan pertumbuhan laba telah banyak dilakukan untuk mendapatan bukti empiris hubungan kinerja dengan pertumbuhan laba. Penelitian mengenai rasio profitabilitas dan pertumbuhan laba telah dilakukan oleh Meilyanti, (2017), Febrianty \& Divianto, (2017), Sayekti Dan Saputra (2015), Afifah, (2016), Andriani, (2015),Sari, Hadi, \& Utami, (2017), Oktatinus \& Adel, (2018), Sari, Paramu, Utami (2018).

Menurut Meilyanti (2017) yang meneliti 8 (delapan) perusahaan sub sektor makanan dan minuman dalam 5 (lima) tahun penelitian dan menemukan hasil bahwa rasio profitabilitas berpengaruh secara simultan terhadap Pertumbuhan Laba sub sektor makanan dan minuman di Bursa Efek Indonesia. Penelitian yang sama dilakukan oleh Febrianty dan Divianto (2017) yang meneliti 14 (empat belas) perusahaan perbankan selama 5 (lima) tahun dan menemukan hasil yang sama dimana rasio profitabilitas dan pertumbuhan laba berpengaruh signifikan secara parsial. Sehingga hipotesa pertama dalam penelitian ini adalah :

\section{$\mathrm{H}_{1}=$ Rasio Profitabilitas berpengaruh terhadap pertumbuhan laba}

\section{Rasio Kinerja Operasi, Rasio Profitabilitas Terhadap Pertumbuhan Laba}

Rasio kinerja operasi digunakan dalam mengevaluasi margin laba dari aktivitas penjualan. Penelitian mengenai rasio kinerja operasi, profitabilitas dan pertumbuhan laba 
telah dilakukan oleh Isnaniah, (2016), Afifah, (2016), Oktatinus \& Adel, (2018), dan Gautama Dan Hapsari (2016). Menurut Isnaniah (2016) yang meneliti 32 (tiga puluh dua) laporan keuangan selama 7 (tujuh) tahun dan menemukan hasil bahwa rasio profitabilitas dan rasio kinerja operasi tidak berpengaruh signifikan terhadap pertumbuhan laba PT Kalbe Farma. Dengan demikian maka hipotesa yang kedua adalah sebagai berikut :

\section{$\mathbf{H}_{2}=$ Rasio Kinerja Operasi memoderasi pengaruh rasio profitabilitas terhadap pertumbuha laba.}

\section{Rasio Pasar, rasio profitabilitas terhadap pertumbuhan laba}

Dalam mengukur nilai saham suatu perusahaan digunakan rasio pasar. Rasio pasar ini berdasar pada sudut investor meskipun pihak manajemen juga memiliki kepentingan yang sama dalam rasio ini. Penelitian mengenai rasio pasar, rasio profitabilitas dan pertumbuhan laba telah dilakukan oleh Sayekti Dan Saputra (2015), Fadila, Saifi (2018), dan Sari, Hadi, \& Utami, (2017). Menurut Sari, Hadi dan Utami (2017) yang meneliti 60 (enam puluh) perusahaan selama 3 (tiga) tahun dan menemukan hasil bahwa rasio profitabilitas berpengaruh terhadap pertumbuhan laba sedangkan rasio pasar tidak berpengaruh terhadap pertumbuhan laba perusahaan. Dengan demikian maka hipotesa yang kedua adalah sebagai berikut :

$\mathrm{H}_{3}=$ Rasio Pasar memoderasi pengaruh rasio profitabilitas terhadap pertumbuha laba.

\section{METODELOGI PENELITIAN}

\section{Objek, Lokasi dan Waktu Penelitian}

Objek penelitian yang sudah ditetapkan oleh peneliti sesuai dengan permasalahan yang akan diteliti yaitu dilakukan pada Perusahaan Manufaktur Sektor Industri dan Kimia yang terdaftar di Bursa Efek Indonesia (BEI) periode 2016 2018, sebanyak 22 (dua puluh dua) perusahaan.

Tabel 1. Daftar Perusahaan Manufaktur Sektor Industri dan Kimia

\begin{tabular}{|c|c|c|c|}
\hline $\begin{array}{l}\mathrm{N} \\
\mathrm{o}\end{array}$ & $\begin{array}{l}\mathrm{KO} \\
\mathrm{DE}\end{array}$ & $\begin{array}{c}\text { NAMA } \\
\text { PERUSAHAAN }\end{array}$ & $\begin{array}{c}\text { SEKTOR } \\
\text { MANUFAKT } \\
\text { UR }\end{array}$ \\
\hline 1 & $\begin{array}{l}\text { AG } \\
\text { II }\end{array}$ & $\begin{array}{l}\text { PT Aneka Gas } \\
\text { Industri Tbk }\end{array}$ & $\begin{array}{c}\text { Industri Dasar } \\
\text { dan Kimia }\end{array}$ \\
\hline 2 & $\begin{array}{l}\text { AK } \\
\text { PI }\end{array}$ & $\begin{array}{l}\text { Argha Karya Prima } \\
\text { Ind. Tbk }\end{array}$ & $\begin{array}{c}\text { Industri Dasar } \\
\text { dan Kimia }\end{array}$ \\
\hline 3 & $\begin{array}{l}\text { AL } \\
\text { KA }\end{array}$ & $\begin{array}{l}\text { PT Alaska } \\
\text { Industrindo }\end{array}$ & $\begin{array}{c}\text { Industri Dasar } \\
\text { dan Kimia }\end{array}$ \\
\hline 4 & $\begin{array}{l}\text { AM } \\
\text { FG }\end{array}$ & $\begin{array}{l}\text { Asahimas Flat } \\
\text { Glass Tbk }\end{array}$ & $\begin{array}{c}\text { Industri Dasar } \\
\text { dan Kimia }\end{array}$ \\
\hline 5 & $\begin{array}{l}\text { AR } \\
\text { NA }\end{array}$ & $\begin{array}{l}\text { Arwana Citramulia } \\
\text { Tbk }\end{array}$ & $\begin{array}{c}\text { Industri Dasar } \\
\text { dan Kimia }\end{array}$ \\
\hline 6 & $\begin{array}{l}\text { BU } \\
\text { DI }\end{array}$ & $\begin{array}{l}\text { PT Budi Starch \& } \\
\text { Sweetener Tbk. }\end{array}$ & $\begin{array}{c}\text { Industri Dasar } \\
\text { dan Kimia }\end{array}$ \\
\hline 7 & $\begin{array}{l}\text { DP } \\
\text { NS }\end{array}$ & $\begin{array}{l}\text { PT Duta Pertiwi } \\
\text { Nusantara Tbk. }\end{array}$ & $\begin{array}{c}\text { Industri Dasar } \\
\text { dan Kimia }\end{array}$ \\
\hline 8 & $\begin{array}{l}\mathrm{IM} \\
\mathrm{PC}\end{array}$ & $\begin{array}{l}\text { PT Impack Pratama } \\
\text { Industri Tbk }\end{array}$ & $\begin{array}{c}\text { Industri Dasar } \\
\text { dan Kimia }\end{array}$ \\
\hline 9 & $\begin{array}{l}\mathrm{IN} \\
\mathrm{AI}\end{array}$ & $\begin{array}{l}\text { Gunawan Dianjaya } \\
\text { Steel Tbk }\end{array}$ & $\begin{array}{c}\text { Industri Dasar } \\
\text { dan Kimia }\end{array}$ \\
\hline $\begin{array}{l}1 \\
0\end{array}$ & $\begin{array}{l}\text { IN } \\
\text { CI }\end{array}$ & $\begin{array}{l}\text { Intanwijaya } \\
\text { Internasional Tbk }\end{array}$ & $\begin{array}{c}\text { Industri Dasar } \\
\text { dan Kimia }\end{array}$ \\
\hline $\begin{array}{l}1 \\
1\end{array}$ & $\begin{array}{l}\text { IPO } \\
\mathrm{L}\end{array}$ & $\begin{array}{l}\text { Indopoly Swakarsa } \\
\text { Industry Tbk }\end{array}$ & $\begin{array}{c}\text { Industri Dasar } \\
\text { dan Kimia }\end{array}$ \\
\hline $\begin{array}{l}1 \\
2\end{array}$ & $\begin{array}{l}\text { ISS } \\
\mathrm{P}\end{array}$ & $\begin{array}{l}\text { PT Steel Pipe Industry } \\
\text { of Indonesia Tbk }\end{array}$ & $\begin{array}{c}\text { Industri Dasar } \\
\text { dan Kimia }\end{array}$ \\
\hline $\begin{array}{l}1 \\
3\end{array}$ & $\begin{array}{l}\text { LIO } \\
\mathrm{N}\end{array}$ & $\begin{array}{l}\text { Lion Metal Works } \\
\text { Tbk }\end{array}$ & $\begin{array}{c}\text { Industri Dasar } \\
\text { dan Kimia }\end{array}$ \\
\hline $\begin{array}{l}1 \\
4\end{array}$ & $\begin{array}{l}\text { PIC } \\
\mathrm{O}\end{array}$ & $\begin{array}{l}\text { Pelangi Indah } \\
\text { Canindo Tbk }\end{array}$ & $\begin{array}{c}\text { Industri Dasar } \\
\text { dan Kimia }\end{array}$ \\
\hline $\begin{array}{l}1 \\
5\end{array}$ & $\begin{array}{l}\mathrm{SM} \\
\mathrm{BR}\end{array}$ & $\begin{array}{l}\text { PT Semen Baturaja } \\
\text { (Persero) Tbk }\end{array}$ & $\begin{array}{c}\text { Industri Dasar } \\
\text { dan Kimia }\end{array}$ \\
\hline $\begin{array}{l}1 \\
6\end{array}$ & $\begin{array}{l}\text { SP } \\
\text { MA }\end{array}$ & Suparma Tbk & $\begin{array}{c}\text { Industri Dasar } \\
\text { dan Kimia }\end{array}$ \\
\hline $\begin{array}{l}1 \\
7\end{array}$ & $\begin{array}{l}\text { SR } \\
\text { SN }\end{array}$ & Indo Acidatama Tbk & $\begin{array}{c}\text { Industri Dasar } \\
\text { dan Kimia }\end{array}$ \\
\hline
\end{tabular}


DOI: http://dx.doi.org/10.35137/jabk.v7i1.381

\begin{tabular}{|c|l|l|c|}
\hline 1 & TA & PT Tunas Alfin Tbk & Industri Dasar \\
8 & LF & dan Kimia \\
\hline 1 & TO & Surya Toto Indonesia & Industri Dasar \\
9 & TO & Tbk & dan Kimia \\
\hline 2 & TR & Trias Sentosa Tbk & Industri Dasar \\
0 & ST & dan Kimia \\
\hline 2 & WS & PT Waskita Beton & Industri Dasar \\
1 & BP & Precast Tbk. & dan Kimia \\
\hline 2 & WT & Wijaya Karya Beton & Industri Dasar \\
2 & ON & dan Kimia \\
\hline
\end{tabular}

\section{Variabel Dan Pengukurannya}

Variabel di dalam penelitian ini terdiri dari variabel independen atau variabel bebas, variabel dependen atau variabel terikat dan variabel moderasi.

Tabel 2. Operasional Variabel

\begin{tabular}{|l|c|l|}
\hline $\begin{array}{c}\text { Varia } \\
\text { bel }\end{array}$ & $\begin{array}{c}\text { Indi } \\
\text { kator }\end{array}$ & \multicolumn{1}{c|}{ Formula } \\
\hline $\begin{array}{l}\text { Rasio } \\
\text { Profit } \\
\text { abilit } \\
\text { as }\end{array}$ & $\begin{array}{c}\text { RO } \\
\text { A } \\
\text { Kiner } \\
\text { ja }\end{array}$ & NP \\
$\begin{array}{l}\text { Oper } \\
\text { asi }\end{array}$ & M & $N P M=\frac{\text { Net Income }}{\text { Total Asset }}$ \\
\hline $\begin{array}{l}\text { Rasio } \\
\text { Pasar }\end{array}$ & EPS & $E P S=\frac{\text { Narning After Tax }}{\text { Jumlah Saham }}$ \\
\hline $\begin{array}{l}\text { Pertu } \\
\text { mbuh } \\
\text { an } \\
\text { Laba }\end{array}$ & PL & $P L$ \\
\hline
\end{tabular}

\section{Populasi dan Sampel Penelitian}

Populasi dari penelitian ini adalah 68 (enam puluh delapan) perusahaan manufaktur sektor industri dan kimia selama periode pengamatan dari tahun 2016 sampai dengan 2018 dari jumlah sampel yang dipilih dalam penelitian ini menggunakan teknik purposive sampling. Data yang digunakan adalah data sekunder yang diperoleh melalui Indonesia Capital Market Directory (ICMD) dan yang telah dipublikasikan melalui situs resmi Bursa Efek Indonesia www.idx.co.id, yaitu laporan keuangan industri dasar dan kimia yang listing di Bursa Efek Indonesia (BEI) tahun 2016-2018.

\section{Metode Analisis Data}

Pengujian hipotesis baik hiotesis pertama, kedua, dan hipotesis ketiga dilakukan dengan Moderated Regression Analysis (MRA). Untuk pengujian hipotesis pertama, kedua dan ketiga pada penelitian ini dilakukan dengan model regresi sebagai berikut :

$$
\begin{aligned}
& \mathbf{Y}=\alpha+\boldsymbol{\beta}_{1} \mathbf{X}_{1}+\boldsymbol{\beta}_{2}\left(\mathbf{X}_{1} \cdot \mathbf{X}_{2}\right)+\boldsymbol{\beta}_{3}\left(\mathbf{X}_{1} \cdot \mathbf{X}_{3}\right) \\
& +\varepsilon
\end{aligned}
$$

Keterangan :

$$
\begin{array}{lll}
\mathrm{Y} & = & \text { Pertumbuhan laba } \\
\alpha & = & \text { Konstan } \\
\beta_{1}, \beta_{2,} \beta_{3}= & \text { Koefisien regresi } \\
\mathbf{X}_{\mathbf{1}} & = & \text { Rasio Profitabilitas } \\
\mathbf{X}_{\mathbf{2}} & = & \text { Rasio Kinerja Operasi } \\
\mathbf{X}_{\mathbf{3}} & = & \text { Rasio Pasar } \\
\varepsilon & & \text { Error }
\end{array}
$$

Dengan melihat tingkat signifikasi, maka dapat dilihat apakah model regresi dapat digunakan dalam memprediksi pengaruh rasio profitabilitas terhadap pertumbuhan laba. Untuk melihat apakah rasio kinerja operasi mempengaruhi hubungan rasio profitabilitas dengan pertumbuhan laba maka dapat dilihat apakah koefisien $\beta_{2}$, secara stastis signifikan. Apabila keofisien $\beta_{2}$ secara statis signifikan maka dapat disimpulkan bahwa rasio kinerja operasi secara stastis mempengaruhi hubungan rasio profitabilitas dengan pertumbuhan laba. Sedangkan untuk melihat apakah rasio pasar mempengaruhi hubungan 
DOI: http://dx.doi.org/10.35137/jabk.v7i1.381

rasio profitabilitas dengan pertumbuhan laba maka dapat dilihat apakah koefisien $\beta_{3}$, secara stastis signifikan. Apabila keofisien $\beta_{3}$ secara statis signifikan maka dapat disimpulkan bahwa rasio pasar secara stastis mempengaruhi hubungan rasio profitabilitas dengan pertumbuhan laba.

\section{HASIL DAN PEMBAHASAN}

Penelitian ini menggunakan data sekunder 22 (dua puluh dua) yang masuk dalam 68 (enam puluh delapan) Perusahaan Manufaktur Sektor Industri dan Kimia serta terdaftar di Bursa Efek Indonesia periode 2016-2018, sehingga diperoleh sebanyak 66 (enam puluh enam) data observasi yang dijadikan sampel penelitian dan sesuai dengan kriteria yang telah ditetapkan

Tabel 1. Statistik Deskriptif

\begin{tabular}{|c|c|c|c|c|c|c|}
\hline & & & Descripti & Statistic & & \\
\hline & $\mathrm{N}$ & $\begin{array}{l}\text { Minim } \\
\text { um }\end{array}$ & $\begin{array}{c}\text { Maximu } \\
\mathrm{m}\end{array}$ & Mc & & $\begin{array}{l}\text { Std. } \\
\text { Deviati } \\
\text { on }\end{array}$ \\
\hline & $\begin{array}{l}\text { ist } \\
\text { ic }\end{array}$ & $\begin{array}{c}\text { Statisti } \\
\mathrm{c}\end{array}$ & Statistic & Statistic & $\begin{array}{l}\text { Std. } \\
\text { Error }\end{array}$ & Statistic \\
\hline RA & 6 & .00132 & .156016 & .045763 & .00412 & .033485 \\
\hline PR & 6 & 62763 & 5256039 & 262743 & 172100 & 019720 \\
\hline $\mathrm{OF}$ & & 03769 & 12 & 378 & 2869 & 506 \\
\hline RA & 6 & .00044 & .170139 & .050858 & .00503 & .040884 \\
\hline KI & 6 & 82150 & 9711434 & 934255 & 249971 & 220958 \\
\hline $\begin{array}{l}\mathrm{NO} \\
\mathrm{P}\end{array}$ & & 22642 & 29 & 165 & 5368 & 971 \\
\hline $\mathrm{PE}$ & 6 & - & 3.74664 & .232436 & .07451 & .605368 \\
\hline RL & 6 & 68972 & 3847380 & 537954 & 571097 & 497692 \\
\hline $\mathrm{AB}$ & & $\begin{array}{l}90935 \\
02766\end{array}$ & 744 & 755 & 2847 & 161 \\
\hline RA & 6 & .28045 & 321.254 & 47.0225 & 6.2278 & 50.5954 \\
\hline PA & 6 & 88039 & 3778801 & 521003 & 748962 & 948363 \\
\hline $\mathrm{S}$ & & 86711 & 84340 & 31190 & 45297 & 65000 \\
\hline
\end{tabular}

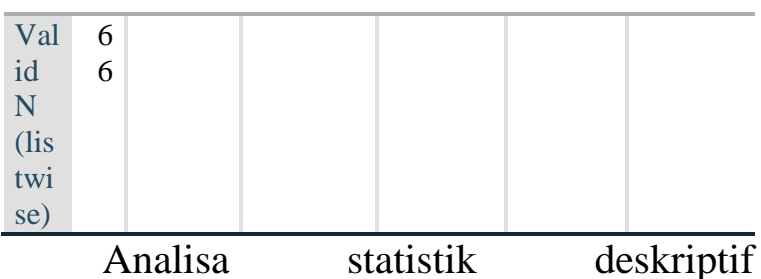

menunjukkan nilai rata-rata dan standar deviasi masing-masing variabel yang diteliti, baik variabel terikat maupun variabel bebas, yang dihitung berdasarkan data secara keseluruhan. Rasio Profitabilitas perusahaan manufaktur yang menjadi sampel dalam penelitian ini berkisar antara 0,00132 sampai 0,15601, dengan nilai rata-rata 0,04576, pada standar deviasi 0,03348 Nilai rata-rata lebih besar dari standar deviasi yaitu $0,04576>0,03348$, menunjukkan bahwa sebaran nilai Rasio Profitabilitas baik. Rasio Profitabilitas tertinggi terjadi pada Surya Toto Indonesia Tbk pada tahun 2018 yaitu sebesar 0,15602 sedangkan Rasio Profitabilitas terendah terjadi pada Asahimas Flat Glass Tbk pada tahun 2018 sebesar 0,00133 .

Rasio Kinerja Operasi perusahaan manufaktur yang menjadi sampel dalam penelitian ini berkisar antara 0,00044, sampai dengan 0,17013 , dengan nilai rata rata 0,05085 , pada standar deviasi 0,04088. Nilai rata-rata lebih besar dari standar deviasi yaitu $0,05085>0,04088$, menunjukkan bahwa sebaran nilai Rasio Kinerja Operasi baik. Rasio Kinerja Operasi tertinggi terjadi pada PT Semen Baturaja (Persero) Tbk pada tahun 2016 yaitu sebesar 0,17014 sedangkan Rasio Kinerja Operasi terendah terjadi pada PT Alaska Industrindo pada Tahun 2016 sebesar 0,00045

Rasio Pasar perusahaan manufaktur yang menjadi sampel dalam penelitian ini berkisar antara 0,28045, sampai dengan 321,25437 , dengan nilai rata rata 47,02255, pada standar deviasi 6,22787. Nilai rata-rata lebih besar dari standar deviasi yaitu 


\section{DOI: http://dx.doi.org/10.35137/jabk.v7i1.381}

47,02255 > 6,22787, menunjukkan bahwa sebaran nilai Rasio Pasar baik. Rasio Pasar tertinggi terjadi pada PT Asahimas Flat Glass Tbk pada tahun 2016 yaitu sebesar 2,506849 sedangkan Rasio Pasar terendah terjadi pada PT Alaska Industrindo pada tahun 2016 sebesar - 0,263650

Pertumbuhan Laba perusahaan manufaktur yang menjadi sampel dalam penelitian ini berkisar antara -0,68972, sampai 3,74664, dengan nilai rata rata 0,23243 , pada standar deviasi 0,60536 . Nilai rata-rata lebih kecil dari standar deviasi yaitu $0,23243<0,60536$, menunjukkan bahwa sebaran nilai Pertumbuhan Laba tidak baik. Pertumbuhan Laba tertinggi terjadi pada PT Waskita Beton Precast Tbk pada tahun 2016 yaitu sebesar 1,62292 sedangkan Rasio Pertumbuhan Laba terendah terjadi pada PT Lion Metal Works Tbk pada tahun 2016 sebesar - 0,02922.

\section{Uji Normalitas}

Uji normalitas atau uji distribusi normal adalah untuk mengukur bahwa data penelitian harus berdistribusi normal sehingga dapat digunakan dalam statistik. Pengujian model regresi dilakukan dengan metode uji Kolmogorov-Smirnov.

Tabel 2. Hasil Uji Normalitas

\section{One-Sample Kolmogorov-Smirnov Test}

Unstandardized Residual

\begin{tabular}{llr}
\hline $\mathrm{N}$ & & 66 \\
\hline $\begin{array}{l}\text { Normal } \\
\text { Parameters }\end{array}$ & Mean & .0000000 \\
\cline { 2 - 3 } & $\begin{array}{l}\text { Std. } \\
\text { Deviation }\end{array}$ & .54327409 \\
\hline $\begin{array}{l}\text { Most Extreme } \\
\text { Differences }\end{array}$ & Absolute & .151 \\
\cline { 2 - 3 } & Positive & .151 \\
\cline { 2 - 3 } & Negative & -.092 \\
\hline Test Statistic & & .151 \\
\hline
\end{tabular}

\begin{tabular}{l} 
Asymp. Sig. (2-tailed) \\
\hline a. Test distribution is Normal. \\
b. Calculated from data. \\
c. Lilliefors Significance Correction.
\end{tabular}

Hasil perhitungan statistik dengan uji normalitas menghasilkan nilai Asymp.Sig dari Kolmogorov-Smirnov $0.001^{\mathrm{c}}<0,05$ artinya H0 ditolak, sehingga menghasilkan model regresi tidak berdistribusi normal.

\section{Uji Multikolinearitas}

Uji Multikoleniaritas dilakukan untuk menguji apakah model regresi ditemukan adanya korelasi antar variabel bebas. Model regresi yang baik adalah tidak terjadi korelasi di antara variabel terikat.

Tabel 3. Hasil Uji Multikolinearitas

\begin{tabular}{|c|c|c|c|c|c|c|c|}
\hline \multirow[b]{3}{*}{ Model } & \multicolumn{5}{|c|}{ Coefficients $^{\mathrm{a}}$} & & \\
\hline & \multicolumn{2}{|c|}{$\begin{array}{l}\text { Unstandar } \\
\text { dized } \\
\text { Coefficien } \\
\text { ts }\end{array}$} & \multirow[t]{2}{*}{$\begin{array}{l}\text { Standar } \\
\text { dized } \\
\text { Coeffici } \\
\text { ents }\end{array}$} & \multirow[b]{2}{*}{$\mathrm{T}$} & \multirow[b]{2}{*}{$\begin{array}{l}\mathrm{Si} \\
\text { g. }\end{array}$} & \multicolumn{2}{|c|}{$\begin{array}{c}\text { Collinearity } \\
\text { Statistics }\end{array}$} \\
\hline & $\mathrm{B}$ & $\begin{array}{c}\text { Std. } \\
\text { Erro } \\
\mathrm{r} \\
\end{array}$ & & & & $\begin{array}{c}\text { Tolera } \\
\text { nce }\end{array}$ & $\begin{array}{l}\text { VI } \\
\mathrm{F} \\
\end{array}$ \\
\hline $\begin{array}{l}1 \text { (Consta } \\
n t)\end{array}$ & .178 & .132 & & $\begin{array}{r}- \\
1.3 \\
44 \\
\end{array}$ & $\begin{array}{r}.1 \\
84\end{array}$ & & \\
\hline $\begin{array}{l}\text { RAPRO } \\
\text { F }\end{array}$ & $\begin{array}{r}16.0 \\
39\end{array}$ & $\begin{array}{r}4.55 \\
4\end{array}$ & .887 & $\begin{array}{r}3.5 \\
22\end{array}$ & $\begin{array}{r}.0 \\
01\end{array}$ & .205 & $\begin{array}{r}4.8 \\
84\end{array}$ \\
\hline $\begin{array}{l}\text { PRORA } \\
\text { PAS }\end{array}$ & $\begin{array}{r}- \\
.007\end{array}$ & .038 & -.027 & $\begin{array}{r}- \\
.19 \\
0\end{array}$ & $\begin{array}{r}.8 \\
50\end{array}$ & .632 & $\begin{array}{r}1.5 \\
82\end{array}$ \\
\hline $\begin{array}{l}\text { PROKI } \\
\text { NOP }\end{array}$ & $\begin{array}{r}- \\
91.9 \\
21 \\
\end{array}$ & $\begin{array}{r}29.6 \\
48\end{array}$ & -.705 & $\begin{array}{r}- \\
3.1 \\
00 \\
\end{array}$ & $\begin{array}{l}.0 \\
03\end{array}$ & .251 & $\begin{array}{r}3.9 \\
83\end{array}$ \\
\hline
\end{tabular}

a. Dependent Variable: PERLAB

Hasil dari perhitungan statistik yang tampak pada tabel 3 diketahui bahwa nilai tolerance dan VIF untuk RAPROF sebesar 0,205 dan 4,884; nilai tolerance dan VIF untuk PRORAPAS sebesar 0,632 dan 1,582; nilai tolerance dan VIF untuk PROKINOP sebesar 0,251 dan 3,983. Sehingga seluruh variable independen pada persamaan regresi mempunyai nilai tolerance $<1$ dan Variance 
DOI: $\underline{\text { http://dx.doi.org/10.35137/jabk.v7i1.381 }}$

inflation factor (VIF) VIF <10. Dengan demikian dapat dikatakan tidak ada multikolinearitas, Ho diterima, artinya Tidak ada Multikolinearitas.

\section{Uji Autokorelasi}

Uji ini ditujukan untuk menguji apakah dalam suatu model regresi linear ada korelasi antar anggota sampel yang diurutkan berdasarkan waktu. Pengujian ini akan dilakukan dengan uji Durbin-Watson dengan melihat hasil regresi berada diluar Autokorelasi ataukah berda di dalam daerah Autokorelasi.

Tabel 4. Hasil Uji Autokorelasi

\begin{tabular}{|c|c|c|c|c|c|}
\hline \multicolumn{6}{|c|}{ Model Summary } \\
\hline $\begin{array}{l}\text { Mod } \\
\text { el }\end{array}$ & $\mathrm{R}$ & $\begin{array}{c}\mathrm{R} \\
\text { Squa } \\
\text { re } \\
\end{array}$ & $\begin{array}{c}\text { Adjust } \\
\text { ed R } \\
\text { Square }\end{array}$ & $\begin{array}{l}\text { Std. Error of } \\
\text { the Estimate }\end{array}$ & $\begin{array}{c}\text { Durbi } \\
\text { n- } \\
\text { Wats } \\
\text { on }\end{array}$ \\
\hline 1 & $\begin{array}{r}.44 \\
1^{\mathrm{a}}\end{array}$ & .195 & .156 & $\begin{array}{r}.556262554931 \\
450\end{array}$ & 2.085 \\
\hline
\end{tabular}

a. Predictors: (Constant), PROKINOP, PRORAPAS, RAPROF

b. Dependent Variable: PERLAB

Berdasarkan pengujian Autokorelasi menggunakan SPSS, didapatkan hasil pengujian Durbin-Watson dengan nilai $2.085(\mathrm{n}=66, \mathrm{k}=3, \mathrm{dl}=1.5079, \mathrm{du}=$ 1.6974) $(4-\mathrm{dl}=2.4921)$ dan $(4-\mathrm{du}=2.3026)$. hasil pengujian ini menunjukkan bahwa nilai Durbin-Watson 2,085 < 2,3026 berada pada area tidak ada autokorelasi.

\section{Uji Heterokedastisitas}

Uji heterokedastisitas bertujuan apakah dalam model regresi terjadi kesamaan variance atau tidak dari residual satu pengamatan ke pengamatan yang lain. Jika variance dari residual satu pengamatan ke pengamatan lain tetap, maka disebut homokedastisitas dan jika berbeda disebut heterokedestisitas. Model regresi yang baik adalah homokedastisitas atau tidak terjadi heterokedetisitas. Uji heteroskedastisitas dilakukan dengan menggunakan scatter plot dan uji glejser.

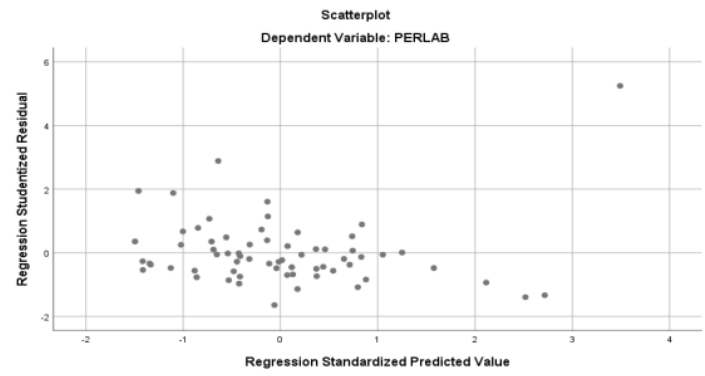

Gambar 5. Scatter Plot Uji Heteroskedatitas

Berdasarkan gambar 5 scatter plot uji heteroskedatitas dapat dilihat bahwa pola yang terbentuk menyebar di atas dan di tengah angka 0 (nol) pada sumbu Y. Dengan demikian dapat disimpulkan bahwa pada model regresi tidak terjadi heteroskedastisitas

\section{Uji Signifikasi Simultan (Uji F)}

Uji statistik F bertujuan untuk mengetahui apakah semua variabel bebas yang dimasukkan dalam model mempunyai pengaruh secara bersama-sama terhadap variabel terikat.

Tabel 6. Tabel Hasil Uji F

\begin{tabular}{l|r|r|r|r|r}
\multicolumn{8}{c}{ ANOVA $^{\text {a }}$} \\
Model & $\begin{array}{c}\text { Sum of } \\
\text { Squares }\end{array}$ & df & Mean & & \\
Square & F & Sig. \\
\hline 1 Regression & 4.636 & 3 & 1.545 & 4.994 & $.004^{\mathrm{b}}$ \\
\hline Residual & 19.185 & 62 & .309 & & \\
\hline Total & 23.821 & 65 & & & \\
\hline
\end{tabular}

a. Dependent Variable: PERLAB

b. Predictors: (Constant), PROKINOP, PRORAPAS, RAPROF

Berdasarkan tabel diperoleh $\mathrm{F}$ hitung sebesar 4,994 dan signifikansi sebesar $0.004^{\mathrm{b}}$ Nilai signifikansi lebih kecil dari 0.05 , hal ini menunjukkan bahwa hipotesis 
ISSN : 2406-7415

e-ISSN : 2655-9919

JURNAL AKUNTANSI DAN BISNIS KRISNADWIPAYANA

Vol. 7 No. 1 (Januari - April) 2020

DOI: $\underline{\text { http://dx.doi.org/10.35137/jabk.v7i1.381 }}$

diterima dan Rasio Profitabilitas, Rasio Kinerja Operasi serta Rasio Pasar secara simultan berpengaruh terhadap Pertumbuhan Laba pada Perusahaan Manufaktur Sektor Industri dan Kimia yang terdaftar di Bursa Efek Indonesia (BEI) periode Tahun 2016 2018.

\section{Uji Koefisien Determinasi (Adj. R2)}

Adjusted R-squared atau pengujian fit ditujukan untuk mengukur seberapa jauh kemampuan model dalam menerangkan variasi variabel bebas dapat dijelaskan oleh variasi Pertumbuhan Laba (PERLAB).

Tabel 7. Tabel Hasil Uji Koefisien Determinasi

\begin{tabular}{|c|c|c|c|c|c|}
\hline \multicolumn{6}{|c|}{ Model Summary ${ }^{b}$} \\
\hline $\begin{array}{l}\text { Mod } \\
\text { el }\end{array}$ & $\mathrm{R}$ & $\begin{array}{c}\mathrm{R} \\
\text { Squa } \\
\text { re } \\
\end{array}$ & $\begin{array}{c}\text { Adjust } \\
\text { ed R } \\
\text { Square }\end{array}$ & $\begin{array}{l}\text { Std. Error of } \\
\text { the Estimate }\end{array}$ & $\begin{array}{c}\text { n- } \\
\text { Wats } \\
\text { on } \\
\end{array}$ \\
\hline 1 & $\begin{array}{r}.44 \\
1^{\text {a }}\end{array}$ & .195 & .156 & $\begin{array}{r}.556262554931 \\
450\end{array}$ & 2.085 \\
\hline
\end{tabular}

a. Predictors: (Constant), PROKINOP,

PRORAPAS, RAPROF

b. Dependent Variable: PERLAB

Dalam tabel 7. diketahui pula nilai koefisien determinasi atau $\mathrm{R}$ Square adalah 0,195 . Nilai R Square 0,195 ini berasal dari pengkuadratan nilai koefisien korelasi atau "R", yaitu $0,441^{\mathrm{a}}$ x $0,441^{\mathrm{a}}=0,195$ Besarnya angka koefisien determinasi ( $\mathrm{R}$ Square) adalah 0,195 atau sama dengan 19,5\% . Angka tersebut mengandung arti bahwa variabel PRORAPAS, RAKINOP, RAPAS, RAPROF, PROKINOP secara simultan (bersama-sama) berpengaruh terhadap variabel Pertumbuhan Laba (Y) sebesar $19,5 \%$. Sedangkan sisanya $(100 \%-19,5 \%=$ $80,5 \%$ ) dipengaruhi oleh variabel lain di luar persamaan regresi ini atau variabel lain yang tidak diteliti.

\section{Analisis Regresi Berganda}

Tabel 8. Tabel Hasil Analisis Regresi Berganda

\begin{tabular}{|c|c|c|c|c|c|}
\hline & C & oefficie & $n t s^{a}$ & & \\
\hline & $\begin{array}{r}\text { Unsta } \\
\text { ze } \\
\text { Coeffi }\end{array}$ & $\begin{array}{l}\text { dardi } \\
\text { d } \\
\text { cients }\end{array}$ & $\begin{array}{l}\text { Standardiz } \\
\text { ed } \\
\text { Coefficien } \\
\text { ts }\end{array}$ & & \\
\hline Model & B & $\begin{array}{l}\text { Std. } \\
\text { Error }\end{array}$ & Beta & $\mathrm{T}$ & Sig \\
\hline 1 (Constant) & -.178 & .132 & & $\begin{array}{r}- \\
1.34 \\
4\end{array}$ & $\begin{array}{r}.18 \\
4\end{array}$ \\
\hline RAPROF & $\begin{array}{r}16.03 \\
9 \\
\end{array}$ & 4.554 & .887 & $\begin{array}{r}3.52 \\
2 \\
\end{array}$ & $\begin{array}{r}.00 \\
1 \\
\end{array}$ \\
\hline $\begin{array}{l}\text { PRORAP } \\
\text { AS }\end{array}$ & -.007 & .038 & -.027 & $\begin{array}{r}- \\
.190 \\
\end{array}$ & $\begin{array}{r}.85 \\
0\end{array}$ \\
\hline PROKIN & - & 29.64 & -.705 & - & .00 \\
\hline & $\begin{array}{r}91.92 \\
1\end{array}$ & 8 & & $\begin{array}{r}3.10 \\
0\end{array}$ & 3 \\
\hline
\end{tabular}

a. Dependent Variable: PERLAB

Berikut penulisan persamaan regresi berdasarkan tabel 8 dari data yang telah diolah dalam penelitian ini:

PERLAB $=-0,178+16,039$ RAPROF 91,921 PROKINOP - 0,007 PRORAPAS +e

1. Konstanta sebesar 0,178 artinya apabila nilai Rasio Profitabilitas, Rasio Kinerja Operasi dan Rasio Pasar sama dengan 0 (nol), maka nlai dari Pertumbuhan Laba sebeasr 0,178

2. $\beta 1=16,039$, setiap kenaikan $1 \mathrm{x}$ rasio profitabilitas, maka pertumbuhan laba akan mengalami kenaikan 1,603\% dengan dugaan variabel lainnya konstan.

3. $\beta 2=91,921$, setiap kenaikan $1 x$ rasio kinerja operasi, maka pertumbuhan laba akan mengalami penurunan 9,192\% dengan dugaan variabel lainnya konstan.

4. $\beta 3=0,007$, setiap kenaikan $1 \mathrm{x}$ rasio pasar, maka pertumbuhan laba akan mengalami penurunan $0,7 \%$ dengan dugaan variabel lainnya konstan

Nilai koefisien dari variabel RAPROF sebesar 16,039 dan menunjukkan bahwa adanya pengaruh positif (+) terhadap 
DOI: $\underline{\text { http://dx.doi.org/10.35137/jabk.v7i1.381 }}$

PERLAB. Nilai koefisien dari variabel PROKINOP sebesar 91,921 dan menunjukkan bahwa adanya pengaruh positif (+) terhadap PERLAB. Nilai koefisien dari variabel PRORAPAS sebesar -0,007 dan menunjukkan bahwa adanya pengaruh negative (-) terhadap PERLAB.

\section{Uji Signifikasi Parameter Individual (Uji t)}

Uji statistik $t$ atau uji persial bertujuan untuk mengetahui seberapa jauh pengaruh variabel bebas secara individual dalam menjelaskan variabel terikat. Berdasarkan tabel 8 hasil uji t, maka hasilnya dapat dijabarkan sebagai berikut:

Hasil perhitungan statistik secara parsial yang terlihat pada tabel 8 adalah sesuai dengan pernyataan hipotesis bahwa rasio profitabilitas sebagai variabel independen berpengaruh positif artinya ketika rasio profitabilitas semakin besar, maka pertumbuhan laba semakin meningkat, dengan nilai koefisien 3,522 dan dengan nilai signifikansi $0,001<0,05$, artinya terdapat pengaruh profitabilitas terhadap pertumbuhan laba. Hasil penelitian menyatakan bahwa $\mathrm{H}_{1}$ diterima.

Hasil perhitungan statistik secara parsial yang terlihat pada tabel 8 adalah sesuai dengan pernyataan hipotesis bahwa rasio kinerja operasi memoderasi pengaruh rasio profitabilitas terhadap pertumbuhan laba. Nilai koefisien PROKINOP sebesar 3,100 dan nilai signifikansi $0,003<0,05$, artinya terdapat pengaruh rasio kinerja operasi yang memoderasi profitabilitas terhadap pertumbuhan laba. Hasil penelitian menyatakan bahwa $\mathrm{H}_{2}$ diterima.

Hasil perhitungan statistik secara parsial yang terlihat pada tabel 8 adalah sesuai dengan pernyataan hipotesis bahwa rasio pasar memoderasi pengaruh rasio profitabilitas terhadap pertumbuhan laba. Nilai koefisien PRORAPAS sebesar -0,190 dan nilai signifikansi $0,850>0,05$, artinya tidak terdapat pengaruh rasio pasar yang memoderasi profitabilitas terhadap pertumbuhan laba. Hasil penelitian menyatakan bahwa $\mathrm{H}_{3}$ ditolak

\section{Pembahasan Hasil Penelitian}

Secara Simultan Hasil Pengaruh Rasio Profitabilitas terhadap Pertumbuhan Laba Dengan Rasio Kinerja Operasi dan Rasio Pasar Sebagai Variabel Moderasi

Berdasarkan hasil analisis data di atas diketahui $\mathrm{F}$ hitung sebesar 4,994 dan nilai signifikansi sebesar $0.004^{\mathrm{b}}<0,05$. Maka Ho ditolak $\mathrm{H}_{1}$ diterima artinya Rasio Profitabilitas, Rasio Kinerja Operasi dan Rasio Pasar secara simultan berpengaruh terhadap Pertumbuhan Laba pada Perusahaan Manufaktur Sektor Industri dan Kimia yang terdaftar di Bursa Efek Indonesia (BEI) Periode Tahun 2016 2018.

Nilai Adjusted R2 sebesar 0,195. Hal ini menunjukkan bahwa Pertumbuhan Laba yang dipengaruhi oleh Rasio Profitabilitas, Rasio Kinerja Operasi dan Rasio Pasar sebesar $19,5 \%$ sedangkan sisanya $80,5 \%$ dipengaruhi oleh variabel lain di luar penelitian ini.

\section{Secara Parsial Hasil Pengaruh Rasio} Profitabilitas terhadap Pertumbuhan Laba Dengan Rasio Kinerja Operasi dan Rasio Pasar Sebagai Variabel Moderasi

Dari Hasil Pengujian atas pengaruh rasio profitabilitas, Rasio Kinerja Operasi dan Rasio Pasar sebagai variabel moderasi diperoleh persamaan 
DOI: http://dx.doi.org/10.35137/jabk.v7i1.381

$$
\mathrm{Y}=\alpha+\beta 1 \mathrm{X} 1+\boldsymbol{\beta} 2(\mathrm{X} 1 . \mathrm{X} 2)+\beta 3(\mathrm{X} 1 .
$$

PERLAB = 0,178 + 16,039 RAPROF 91,921 PROKINOP - 0,007 PRORAPAS +e

Rasio Profitabilitas berpengaruh positif terhadap Pertumbuhan Laba pada Perusahaan Manufaktur Sektor Industri dan Kimia yang terdaftar di Bursa Efek Indonesia (BEI) periode 2016 - 2018. Hasil analisis data hipotesis pertama diketahui bahwa nilai $t$ hitung bernilai positif yaitu sebesar 3,522 dan dengan nilai signifikansi $0,001<0,05$, sehingga dapat disimpulkan bahwa rasio profitabilitas berpengaruh signifikan terhadap pertumbuhan laba.

Rasio Kinerja Operasi memoderasi pengaruh rasio profitabilitas terhadap pertumbuha laba pada Perusahaan Manufaktur Sektor Industri dan Kimia yang terdaftar di Bursa Efek Indonesia (BEI) periode 2016 - 2018. Hasil analisis data hipotesis kedua diketahui bahwa nilai $t$ hitung bernilai negatif yaitu sebesar 3,100 dengan tingkat signifikasi sebesar 0,003 < 0,05 sehingga dapat disimpulkan bahwa rasio kinerja operasi yang memoderasi rasio profitabilitas berpengaruh signifikan terhadap pertumbuhan laba.

Rasio Pasar memoderasi pengaruh rasio profitabilitas terhadap pertumbuhan laba pada Perusahaan Manufaktur Sektor Industri dan Kimia yang terdaftar di Bursa Efek Indonesia (BEI) periode 2016 - 2018. Hasil analisis data hipotesis ketiga diketahui bahwa nilai t hitung bernilai negatif yaitu sebesar 0,190 dengan tingkat signifikasi sebesar $0,850>0,05$ sehingga dapat disimpulkan bahwa rasio pasar yang memoderasi rasio profitabilitas tidak berpengaruh signifikan terhadap pertumbuhan laba.

\section{KESIMPULAN DAN SARAN}

\section{Kesimpulan}

Penelitian ini ditujukan untuk mengetahui pengaruh Rasio Profitabilitas terhadap pertumbuhan laba dengan Rasio Kinerja Operasi dan Rasio pasar sebagai variabel moderasi. Hasil penelitian ini merupakan hasil penglolahan data dengan menggunakan SPSS versi 25. Dari hasil pengujian statistik yang telah penulis lakukan, maka penulis ingin menarik kesimpulan sebagai berikut:

1. Berdasarkan hipotesis pertama, variabel Rasio Profitabilitas menunjukkan terdapat pengaruh positif dan signifikan terhadap Pertumbuhan Laba sehingga $\mathrm{H}_{1}$ diterima. Profitabilitas merupakan rasio atau perbandingan untuk mengetahui kemampuan perusahaan untuk mendapatkan laba (profit) dari pendapatan (earning) terkait penjualan, aset, dan ekuitas berdasarkan dasar pengukuran tertentu. Rasio profitabilitas diperlukan untuk pencatatan transaksi keuangan biasanya dinilai oleh investor dan kreditur (bank) untuk menilai jumlah laba investasi yang akan diperoleh oleh investor dan besaran laba perusahaan untuk menilai kemampuan perusahaan membayar utang kepada kreditur berdasarkan tingkat pemakaian aset dan sumber daya lainnya sehingga terlihat tingkat efisiensi perusahaan. Karena Hipotesa $\left(\mathrm{H}_{1}\right)$ diterima, maka Rasio Profitabilitas atau ROA dapat digunakan untuk memprediksi Pertumbuhan Laba pada Perusahaan Manufaktur Sektor Industri dan Kimia 
DOI: $\underline{\text { http://dx.doi.org/10.35137/jabk.v7i1.381 }}$

yang terdaftar di Bursa Efek Indonesia (BEI) periode Tahun 2016 - 2018.

2. Berdasarkan hipotesis kedua, variabel Rasio Kinerja Operasi yang memoderasi Rasio Profitabilitas terhadap Pertumbuhan Laba menunjukkan terdapat pengaruh negatif yang signifikan terhadap Pertumbuhan Laba sehingga $\mathrm{H}_{2}$ diterima. Hasil penelitian ini menunjukkan bahwa Semakin besar nilai Rasio Kinerja Operasi menunjukkan semakin efisien perusahaan tersebut dalam mengeluarkan biaya-biaya sehubungan dengan kegiatan operasinya, maka kinerja perusahaan akan semakin produktif sehingga akan meningkatkan kepercayaan investor untuk menanamkan modalnya pada perusahaan tersebut. Karena Hipotesa $\left(\mathrm{H}_{2}\right)$ diterima, maka Rasio Kinerja Operasi yang memoderasi Rasio Profitabilitas terhadap Pertumbuhan Laba dapat digunakan untuk memprediksi Pertumbuhan Laba pada Perusahaan Manufaktur Sektor Industri dan Kimia yang terdaftar di Bursa Efek Indonesia (BEI) periode Tahun 2016 - 2018.

3. Berdasarkan hipotesis ketiga, variabel Rasio Pasar yang memoderasi Rasio Profitabilitas terhadap Pertumbuhan Laba menunjukkan terdapat pengaruh negatif dan tidak signifikan terhadap Pertumbuhan Laba, sehingga hipotesis ketiga ditolak. Informasi Rasio Pasar suatu perusahaan menunjukkan besarnya laba bersih perusahaan yang siap dibagikan untuk semua pemegang saham perusahaan. Earning Per Share merupakan rasio yang menunjukkan berapa besar keuntungan atau return yang diperoleh investor atau pemegang saham per lembar saham. Karena Hipotesa $\left(\mathrm{H}_{3}\right)$ ditolak, maka Rasio Pasar yang memoderasi Rasio Profitabilitas terhadap Pertumbuhan Laba tidak dapat digunakan untuk memprediksi Pertumbuhan Laba pada Perusahaan Manufaktur Sektor Industri dan Kimia yang terdaftar di Bursa Efek Indonesia (BEI) periode Tahun 2016 - 2018.

\section{Saran}

Penelitian ini memiliki beberapa keterbatasan dan kelemahan sehingga mempengaruhi hasil penelitian, diantaranya sebagai berikut:

1. Penelitian ini hanya mengambil jangka waktu 3 (tiga) tahun yaitu dari tahun 2016 sampai dengan 2018, sehingga data yang diambil terdapat kemungkinan kurang mencerminkan kondisi perusahaan dalam jangka panjang. Sebaiknya penelitian selanjutnya tidak hanya terbatas pada jangka waktu 3 (tiga) tahun agar dapat mencerminkan kondisi perusahaan dalam jangka panjangmya

2. Sebaiknya perusahaan yang dijadikan sampel dalam penelitian ini tidak hanya terbatas pada Perusahaan Manufaktur Sektor Industri dan Kimia yang terdaftar di Bursa Efek Indonesia (BEI)

\section{DAFTAR PUSTAKA}

Afifah, M. (2016). LABA PADA PERUSAHAAN MANUFAKTUR YANG TERDAFTAR DI BURSA EFEK INDONESIA TAHUN 2011- 
ISSN : 2406-7415

e-ISSN : 2655-9919

JURNAL AKUNTANSI DAN BISNIS KRISNADWIPAYANA

Vol. 7 No. 1 (Januari - April) 2020

DOI: http://dx.doi.org/10.35137/jabk.v7i1.381

2014. Universitas Nusantara PGRI Kediri.

Andriani, I. (2015). PENGARUH RASIO KEUANGAN TERHADAP

PERTUMBUHAN LABA PADA PERUSAHAAN PERTAMBANGAN YANG TERDAFTAR DI BURSA EFEK INDONESIA Ima Andriyani 1.

Ang, R. (1997). Buku Pintar : Pasar Modal Indonesia. Jakarta: Media Soft Indonesia.

Baker, R. E., Christensen, T. E., Cottrell, D. M., Kurnia, I. R., Astono, W., \& Wulandari, E. R. (2015). Akuntansi Keuangan Lanjutan. Jakarta: Salemba Empat.

Bringham, E. F., \& Joul, F. H. (2014). Dasar-dasar Manajemen Keuangan. Jakarta: Salemba Empat.

Chariri, A., \& Ghozali, I. (2007). Teori Akuntansi. Semarang: Badan Penerbit Universitas Diponegoro.

Copeland, T. E., \& Weston, J. F. (1982). A Note on the Evaluation of Cancellable Operating Leases. Financial Management.

https://doi.org/10.2307/3665025

Darmadji, T., \& Fakhrudin, H. M. (2011). Pasar Modal di Indonesia: Pendekatan Tanya Jawab. Jakarta: Salemba Empat.

Darsono, \& Ashari. (2005). Pedoman Praktis Memahami Laporan Keuangan. Yogyakarta: CV. Andi Offset.

Dwi, P. (2017). ANALISIS LAPORAN KEUANGAN KONSEP DAN APLIKASI (3rd ed.). UPP STIM YKPN.

Febrianty, \& Divianto. (2017). Pengaruh Rasio Keuangan Terhadap Pertumbuhan Laba Perusahaan Perbankan, 12(2).

Gunawan, A. D. E., \& Wahyuni, S. R. I. F. (2013). PENGARUH RASIO KEUANGAN TERHADAP PERTUMBUHAN LABA PADA 
DOI: $\underline{\text { http://dx.doi.org/10.35137/jabk.v7i1.381 }}$

Sampoerna Tbk. Jurnal EMBA, 1(3), 619-628.

Meilyanti. (2017). ANALISIS PENGARUH RASIO KEUANGAN TERHADAP PERTUMBUHAN LABA PADA SUB SEKTOR MAKANAN DAN MINUMAN DI BURSA EFEK INDONESIA PERIODE, 5(4), 10001013.

Munte, M. H. M., \& Sitanggang, T. T. (2017). EFFECT OF FINANCIAL RATIOS ON THE GROWTH OF PROFIT IN MANUFACTURING INDUSTRY LISTED IN INDONESIA STOCK EXCHANGE, (77544).

Oktatinus, \& Adel, J. F. (2018). PENGARUH CURRENT RATIO, DEBT TO ASSET RATIO, TOTAL ASSET TURNOVER, NET PROFIT MARGIN DAN RETURN ON ASSET TERHADAP PERTUMBUHAN LABA PADA PERUSAHAAN MANUFAKTUR YANG TERDAFTAR DI BURSA EFEK INDONESIA PERIODE 2013-2014.

Porter, M. E. (1980). Competitive Strategy: Techniques for Analyzing Indstries and Competitors. The Free Press.

Purnasiwi, J. dan S. (2011). Analisis
Pengaruh Size, Profitabilitas Dan Leverage Terhadap Pengungkapan Csr Pada Perusahaan Yang Terdaftar Di Bursa Efek Indonesia, (February), 1-63. Sari, D. P., Hadi, P., \& Utami, E. S. (2017). Analisis Pengaruh Rasio Keuangan dan Ukuran Aset Pada Pertumbuhan Laba Perusahaan Manufaktur Yang Terdaftar Pada Bursa Efek Indonesia Periode 2010-2013 The Influence of Financial Ratios and Asset Size on Earning Growth of Manufacture Companies Listed in t, $I V(2007)$, 63-66.

Sekaran, U. (2015). Jenis Olah Data. Semarang.

Siyoto, S. (2015). Dasar Metodologi Penelitian.

Sugiono, A. (2016). Panduan Praktis Dasar Analisis Laporan Keuangan. Jakarta.

Syahyunan. (2015). Manajemen Keuangan: Perencanaan, Analisis, dan Pengendalian Keuangan. Medan: USU Press.

Wijaya, D. (2017). Manajemen Keuangan Konsep dan Penerapannya. Jakarta.

Wild, J. J., Subramanyam, K. R., \& Robert F, H. (2015). Financial Statement Analysis (10th ed.). McGrawHill.Boston. 